\title{
Kewajiban Masyarakat untuk Menanam Tanaman Kina
}

Sasiki Rana

IIK SURYA MITRA HUSADA

ranasasiki@gmail.com

\begin{abstract}
Abstrak
penelitian terhadap tanaman kina ini bertujuan untuk membuktikan kandungan yang terdapat pada tanaman kina bias berfungsi untuk meningkatkan antibodi dan imun tubuh. Dikatakan kulit pada tanaman ini terdapat kandungan senyawa klorokuin yang juga bias menjadi obat untuk orang terkena virus covid-19, dan juga bias meminimalisir kerusakan organ tubuh karena terpapar virus corona. Akan tetapi keakuratan tanaman kina menjadi obat untuk virus corona masih tetap diteliti hingga kini. Tanaman kina sendiri juga memiliki kandungan alkaloid yang biasa digunakan untuk mengobati penyakit malaria dan masih banyak lagi manfaat tanaman kina.
\end{abstract}




\section{Latar belakang}

Tanaman kina adalah tanaman obat yang sudah dikenal sejak lama. Tanaman ini berasal dari hutan amerika selatan. Tanaman ini bisa diambil dan dimanfaatkan bagian kulitnya karena banyak mengandung zatalkaloid alkaloid sehingga bermanfaat menjadi obat herbal. Secara garis besar kandungan alkaloid ini berfungsi untuk mengobati penyakit malaria dan gangguan jantung. Tanaman kina juga memiliki kandungan klorokuin yang sangat bermanfaat bagi tubuh yaitu memelihara kekebalan imun dan meningkatkan antibodi tubuh. Bahkan juga disebutkan bahwa tanaman kina dapat meminimalisir dampak dari virus corona yang menyerang tubuh dan bahkan juga dikatakan dapat meminimalisir kita akan paparan virus corona yang menyerang umat manusia karena tanaman kia sendiri mengandung zat yang bisa memelihara imun dan meningkatkan antibodi dalam tubuh.

\section{Kasus makalah}

1. Bagaimana tanaman kina bisa membangun imun dan menjaga antibodi tubuh?

2. Benarkah tanaman kina bisa menjadi obat untuk orang yang terjangkit virus corona?

\section{Tinjauan pustaka}

Didalam tanaman kina terdapat berbagai senyawa salah satunya yaitu senyawa klorokuin fosfat. Senyawa ini sudah pernah diteliti pada kera oleh seorang ahli virologi dari Wuhan Institute of Virology dari Chenese Academy of Scince, Manli Wang bersama timnya. Berdasarkan penelitian awal yang dilakukan Wang dan 
timnya, klorokuin dapat menghambat kemampuan virus baru untuk menginfeksi dan tumbuh di dalam sel, saat diujikan pada kera. Laporan penelitian yang dilakukan Wang dan timnya tentang kandungan klorokuin fosfat telah dipublikasikan di jurnal nature. Selain klorokuin eksperimentak yang disebut remdesivir juga memiliki mekanisme yang sama saat menghentikan pertumbuhan virus yang ada didalam manusia. Klorokuin juga disebutkan mampu untuk membantu sistem kekebalan tubuh melawan virus tanpa jenis reaksi berlebihan yang dapat menyebabkan kegagalan organ.

\section{Pembahasan}

Didalam tanaman kina terdapat kandungan alkaloid dan juga memiliki senyawa klorokuin fosfat. Alkaloid merupakan sebuah golongan senyawa basa berniterogen yang kebanyakan heterosiklik dan tumbuh pada tanaman. Alkaloid secara umum memilili beberapa manfaat yaitu untuk memacu sistem saraf, menjaga kestabilan tekanan darah, dan juga melawan infeksi mikroba dalam tubuh. Sedangkan alkaloid yang terdapat pada tanaman kina dibagi terdiri dari kuinin, kuinidin, dan sinkona yang digadang gadang menjadi agen malaria. Tanaman kina juga memiliki kandungan senyawa klorokuin. Senyawa klorokuin merupakan senyawa yang terdapat pada kulit batang dan ranting tanaman kina yang dijadikan obat sejak lama. Kandungan klorokuin ini mampu untuk menjaga imun dan meningkatkan antibodi tubuh. Senyawa klorokuin fosfat yang terdapat pada tanaman kina juga disebutkan mampu untuk menjadi obat untuk virus corona. Kandungan senyawa ini telah diujikan pada kera oleh peneliti di china. Dan juga dikatakan bahwa senyawa klorokuin selain dapat digunakan untuk obat malaria juga mampu 
untuk digunakan meminimalisir dampak paparan virus corona dan juga dapat mencegah dampak yang fatal berupa kegagalan organ tubuh. Kandungan senyawa klorokuin ini dikatakan dapat meminimalisir terpaparnya tubuh kita dari virus corona karena kandungan yang terdapat pada tanaman kina mampu menjaga imun dan meningkatkan kekebalan tubuh kita. Akan tetapi masih perlu diteliti dan diuji lagi keakuratan tanaman kina ini untuk dijadikan obat yang valid dari virus corona yang sudah banyak memakan korban jiwa.

\section{Kesimpulan}

Tanaman kina adalah salahsatu dari sekian banyak tanaman obat yang udah dikenal sejak lama. Tanaman kina juga ditemukan di hutan Amerika selatan,akan tetapi banyak juga ditemukan di beberapa daerah yang ada di Indonesia. Tanaman kina memiliki banyak manfaat yang baik bagi kesehatan, salah satunya yaitu meningkatkan imun dan antibodi dalam tubuh dan digadang gadang mampu dijadikan obat dan antivirus covid-19.

Akan tetapi, saat ini populasi tanaman kina semakin berkurang. Seiring perkembangan zaman lahan untuk menanam di Indonesia semakin berkurang karena pembangunan besar besaran di perkotaan maupun juga pedesaan. Masyarakatpun juga sudah mulai kurang menggiati untuk Bertani padahal manfaat dari tanaman ini sangatlah penting untuk menjaga imun dan miningkatkan kekebalan antibodi tubuh. 


\section{Daftar pustaka}

Dinda Silviana Dewi."klorokuin dalam Pohon Kina Diprediksi Bisa Obati Corona COVID-19",https://amp.tirto.id/klorokuin-dalampohon-kina-diprediksi-bisa-obati-corona-covid-19-eEyq

Lanny Latifah."Pohon Kina,Tanaman Herbal yang Miliki Banyak Manfaat,Mengobati Malaria hingga Jantung",https://m.tribunnews.com/amp/kesehatan/2020/03/12/po hon-kina-tanaman-herbal-yang-miliki-banyak-manfaat-mengobatimalaria-hingga

\section{"Kina Tanaman Multi}

Manfaat",https//www.litbang.pertanian.go.id/tahukah-anda/78/ 